\title{
Analisa Kerusakan Pompa OCCWP Pada Pembangkit Listrik Tenaga Uap 2 × 115 MW
}

\author{
Tambos August Sianturi ${ }^{1{ }^{* *}, \text { Sindak Hutauruk }}{ }^{2}$, Fiktor Sihombing ${ }^{2}$ \\ ${ }^{1}$ Prodi Teknik Mesin Universitas HKBP Nommensen Pematangsiantar \\ ${ }^{2}$ Prodi Teknik Elektro Universitas HKBP Nommensen, Medan \\ *tambos.sianturi73@gmail.com
}

\begin{abstract}
The use of pumps in the industrial world, especially in power plants, cannot be separated from problems that arise that can cause losses. The research was conducted at PLTU 2 X 115 MW by taking a case that had happened to the pump, namely the Open Cycle Cooling Water Pump 2A. The analytical method used in this final project is the vibration analysis method, namely by reading the spectrum of the data retrieval results so that it can be seen what happens to the equipment that experiences an increase in vibration.

Bearing damage can be seen in the spectrum image of the measurement results, where the appearance of the spectrum in the high frequency range is an indication of bearing damage. And the high vibration which reaches $13.06 \mathrm{~mm} / \mathrm{s}$ and is already in the danger category based on ISO 10816-3.
\end{abstract}

Keywords: pump, bearing, vibration analysis, spectrum, ISO 10816-3.

\section{PENDAHULUAN}

Pompa adalah suatu alat atau mesin yang digunakan untuk memindahkan cairan dari suatu tempat ke tempat yang lain melalui suatu media perpipaan dengan cara menambahkan energi pada cairan yang dipindahkan dan berlangsung secara terus menerus.

Pompa merupakan salah satu komponen penting pada pembangkit listrik. Pada pembangkit listrik, pompa digunakan sebagai alat untuk menaikkan tekanan fluida atau mengalirkan fluida menuju sebuah peralatan lain. Pada pembangkit listrik, pompa beroperasi 24 jam tanpa henti bahkan saat pembangkit listrik tidak beroperasi pompa tetap beroperasi untuk menyuplai air pendingin peralatan.

Seiring berkembangnya ilmu pengetahuan dan teknologi, teknik analisa pada pompa kini lebih mudah, lebih efesien dan lebih cepat. Untuk menganalisa kondisi pompa kini menggunakan alat yang lebih canggih walaupun sebenarnya harga alat ini sangat mahal. Salah satu metode yang saat ini digunakan untuk menganalisa pompa adalah menggunakan metode vibration analysis. Penggunaan alat vibration analyzer pada pembangkit listrik saat ini sangat penting untuk mengetahui kondisi suatu pompa. Penggunaan alat Vibration Analyzer memang mahal, tetapi jika dihitung dari segi masalah kerugian biaya akibat pemeliharaan jangka panjang maka akan lebih menguntungkan membeli dan menggunakan alat tersebut untuk menganalisa. Berdasarkan latar belakang tersebut maka timbul pemikiran penulis untuk melakukan analisa kerusakan pompa pada PLTU 2 X 115 MW.

Disini peneliti akan membahas tentang cara menganalisa kondisi suatu pompa menggunakan alat vibration analyzer, dimana analisa menggunakan alat tersebut akan lebih efisien dan lebih mudah dilakukan. Dari analisa menggunakan alat vibration analyzer kita dapat menyimpulkan kondisi suatu pompa tanpa harus melakukan pembongkaran fisik dari pompa tersebut. 


\section{LANDASAN TEORI}

Pompa adalah salah satu jenis mesin fluida yang berfungsi untuk memindahkan zat cair dari suatu tempat ke tempat lain yang diinginkan. Pompa beroperasi dengan membuat perbedaan tekanan antara bagian masuk (suction) dengan bagian keluar (discharge). Pompa juga berfungsi mengubah tenaga mekanis dari suatu sumber tenaga penggerak menjadi tenaga kinetis (kecepatan). Tenaga ini berguna untuk mengalirkan cairan dan mengatasi hambatan yang ada di sepanjang aliran. Pompa diklasifikasikan seperti gambar 1 berikut ini.

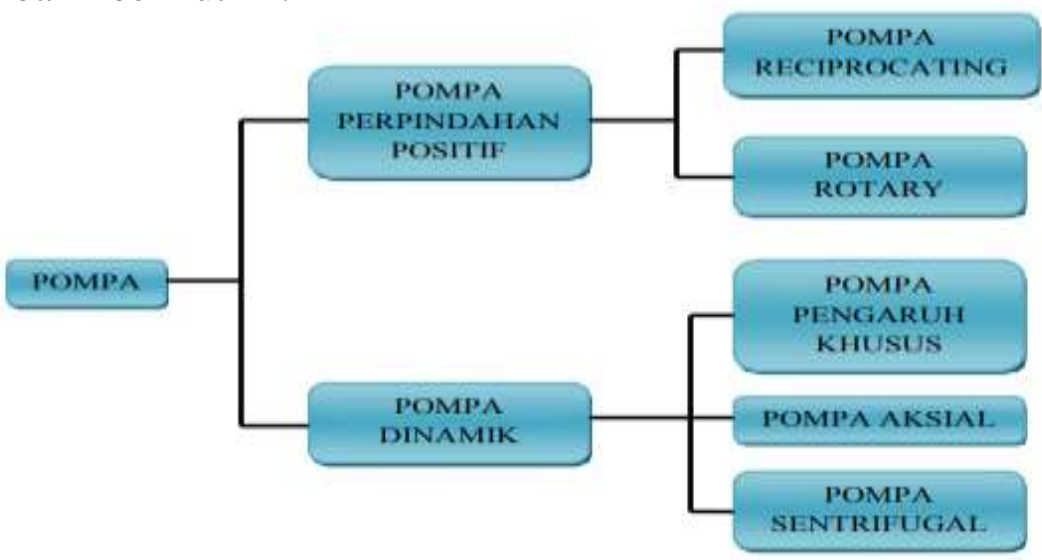

Gambar 1. Klasifikasi Pompa

(Sumber : Pengklasifikasian Pompa)

\subsection{Pompa Perpindahan Positif (Positif Displacment Pump)}

Pompa perpindahan positif bekerja dengan cara memberikan gaya tertentu pada volume fluida tetap dari sisi inlet menuju ke sisi outlet pompa. Kelebihan dari pengguanaan pompa jenis ini adalah dapat menghasilkan power density (gaya persatuan berat) yang lebih berat dan memberikan perpindahan fluida yang tetap atau stabil di setiap putarannya.

Pompa perpindahan positif memiliki tipe yang lebih bervariasi dari pada pompa dinamik. Secara general pompa perpindahan positif dibagi menjadi dua yaitu jenis pompa rotary dan jenis reciprocating.

a. Pompa Rotary

Pompa rotary ini memindahkan fluida kerja melalui mekanisme rotary dengan jalan menimbulkan efek vakum sehingga dapat menghisap fluida kerja dari sisi inlet, dan memindahkannya ke sisi outlet. Terperangkapnya udara di dalam rotary, secara natural pompa ini akan mengeluarkan udara tersebut. Jenis pompa rotary antara lain pompa roda gigi, pompa screw dan pompa kipas.
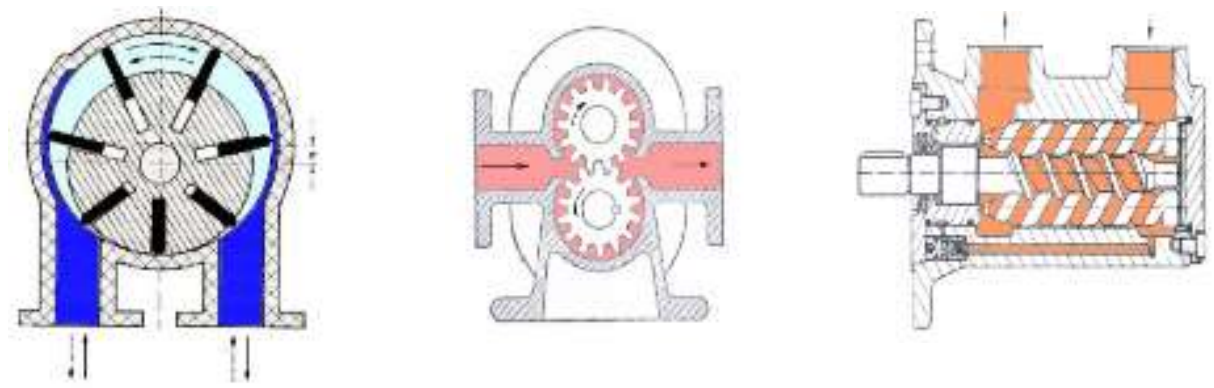

Gambar 2. Pompa Kipas, Pompa Roda Gigi, Pompa Screw

(Sumber : puballattack.blogspot.co.id/pengertian-pompapompa-kipas.html) 


\subsection{Pompa Dinamik (Dynamic Pump)}

Pompa dinamik terbagi menjadi beberapa macam yaitu pompa sentrifugal, pompa aksial dan pompa spesial efek atau pompa pengaruh khusus. Pompa- pompa ini beroperasi dengan menghasilkan kecepatan fluida tinggi dan mengkonversi kecepatan menjadi tekanan melalui perubahan penampang aliran fluida. Jenis pompa ini biasanya juga memiliki efisiensi yang lebih rendah dari pada tipe pompa perpindahan positif, tetapi memiliki biaya yang rendah untuk perawatannya. Pompa dinamik juga bisa beroperasi pada kecepatan yang tinggi dan debit aliran yang juga tinggi. Berikut jenisjenis pompa dinamik.

\section{a. Pompa Sentrifugal}

Sebuah pompa sentrifugal tersusun atas sebuah impeller dan saluran inlet ditengahtengahnya. Dengan desain ini maka pada saat impeller berputar, fluida mengalir menuju casing disekitar impeller sebagai akibat dari gaya sentrifugal. Casing ini berfungsi untuk menurunkan kecepatan aliran fluida sementara kecepatan putar impeller tetap tinggi. Kecepatan fluida dikonversikan menjadi tekanan oleh casing sehingga fluida dapat menuju titik outlet nya.

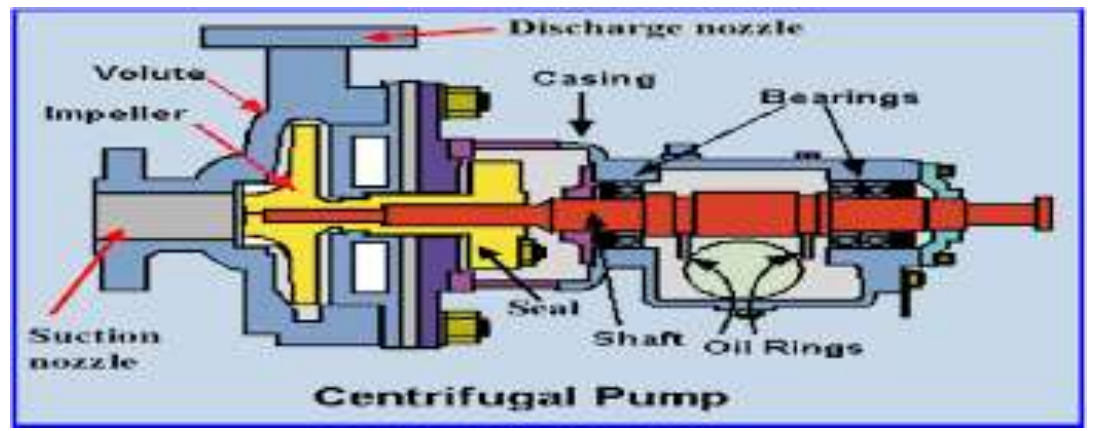

Gambar 3. Pompa Sentrifugal

(Sumber : www.insinyoer.com/prinsip-kerja-pompa-centrifugal)

\section{b. Pompa Aksial}

Pompa aksial bisa juga disebut dengan pompa propeler. Pompa ini menghasilkan sebagian besar tekanan dari propeller dan gaya lifting dari sudu terhadap fluida. Pompa ini banyak digunakan pada sistem drainase dan irigasi. Pompa aksial vertikal single stage lebih umum digunakan, akan tetapi kadang pompa aksial two stage lebih ekonomis penerapannya. Pompa aksial horisontal digunakan untuk debit aliran fluida yang besar dengan tekanan yang kecil dalam alirannya.

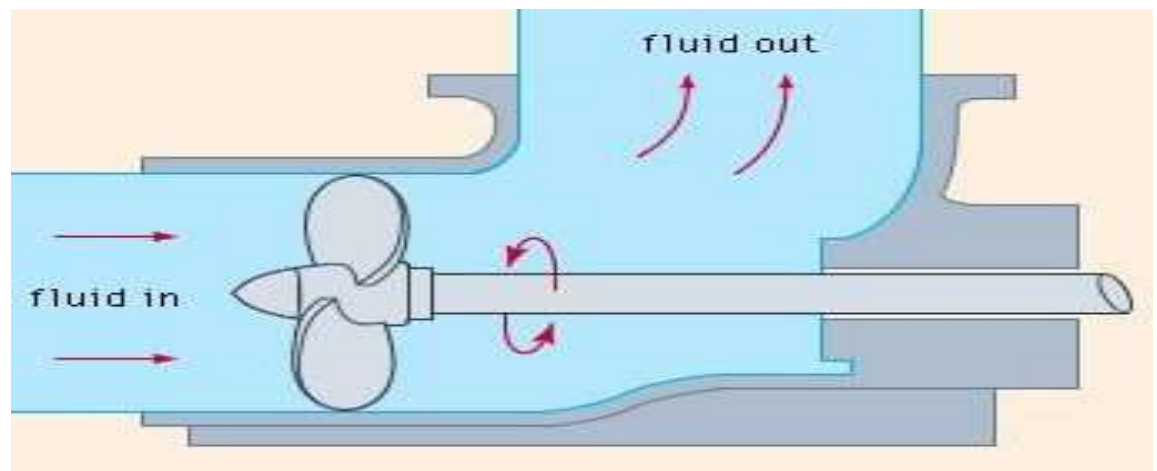

Gambar 4. Pompa Aksial

(Sumber : chemicalengginfo.org/2017/05/28/axial-flow-pumps) 


\section{METODOLOGI PENULISAN}

\section{Waktu dan Tempat Penelitian}

1. Tempat penelitian analisa kerusakan pompa OCCWP ini direncanakan dan dilaksanakan di PLTU Labuhan Angin di Sibolga, Tapanuli Tengah.

2. Waktu pelaksanaan penelitian analisa kerusakan pompa OCCWP ini diperkirakan selama 4 (empat) minggu.

\subsection{Metode Pengambilan Data Vibrasi}

Pada pengukuran getaran diwajibkan dilakukan pada bagian yang tidak tersembunyi pada mesin yang biasanya lokasi tersebut mudah di akses dan yang mewakili rambatan gaya pada support struktur, sebagai contoh pada semua main bearing dari equipment.

Contoh umum lokasi pengukuran ditunjukkan pada gambar 5. Perlu diperhatikan bahwa dalam konteks ini, untuk memastikan bahwa pengukuran sudah cukup mewakili getaran bearing housing, dan tidak mengikutsertakan resonansi lokal ataupun amplifikasi. Lokasi dan arah untuk pengukuran getaran paling tidak harus menyediakan sensitifitas yang memadai bagi gaya dinamik mesin dalam berbagai macam kondisi operasi. Seringkali ini akan membutuhkan dua arah pengukuran ortogonal radial pada masing-masing bearing cap, pedestal atau housing.

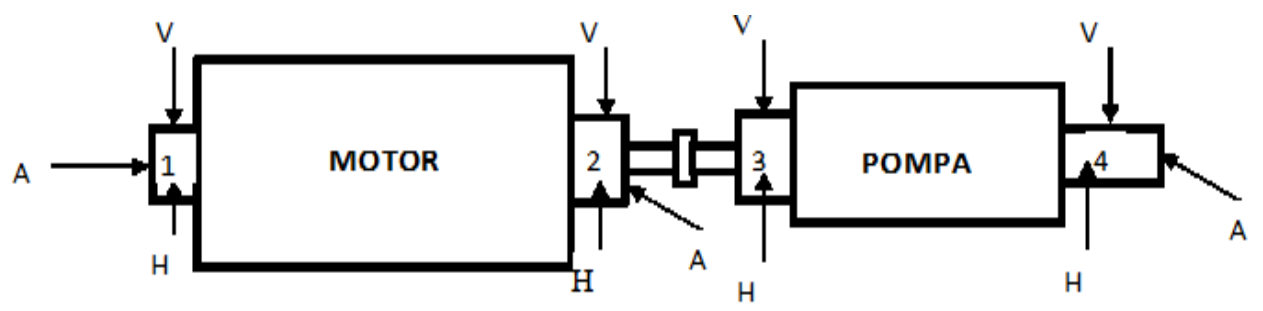

Gambar 5. Titik pengukuran pada horizontal equipment assembly (Sumber : Laptek Vibrasi PUSLITBANG)

dimana :

$$
\begin{aligned}
& 1=\text { Bearing NDE Motor } \\
& 2=\text { Bearing DE Motor } \\
& 3=\text { Bearing DE Pompa } \\
& 4=\text { Bearing NDE Pompa }
\end{aligned}
$$

Posisi pengambilan :

$\mathrm{H}=$ Horizontal

$\mathrm{V}=$ Vertikal

A = Axial

Untuk mengetahui peralatan tersebut dalam kondisi baik, getaran pada peralatan pembangkit tersebut harus dibawah dari batasan yang telah ditetapkan oleh standard. Standard yang digunakan pada pengukuran getaran pada peralatan rotary machine industri umum menggunakan ISO 10816-3. 

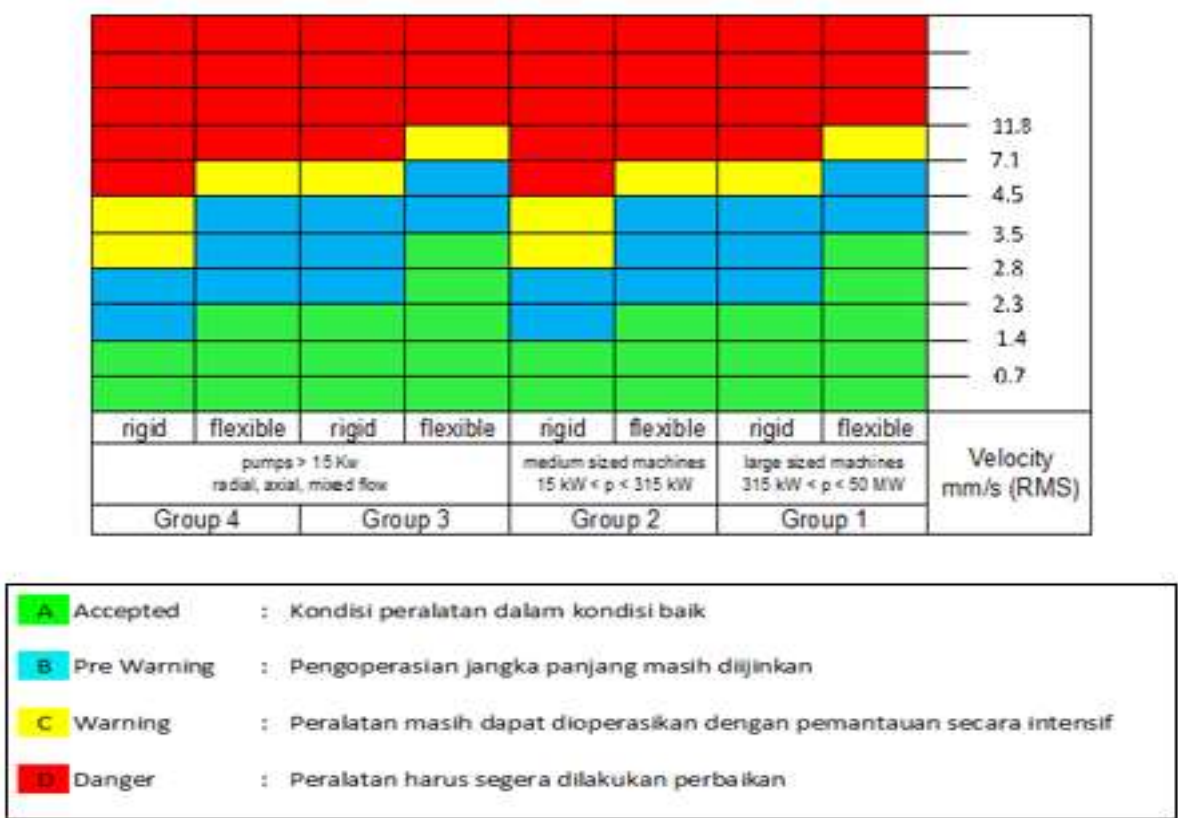

Gambar 6. Standard ISO 1081-3

(Sumber : Laptek Vibrasi PUSLITBANG)

\subsection{Bahan dan Alat}

\subsubsection{Peralatan/instalasi mesin}

Pada penelitian yang akan dilakukan kali ini, peralatan yang akan diuji adalah open cooling cycle water pump pada PLTU Labuhan Angin. Dimana pompa tersebut berfungsi untuk mengalirkan air pendingin sistem terbuka menuju heat exchanger untuk mendinginkan air pendingin sistem tertutup.

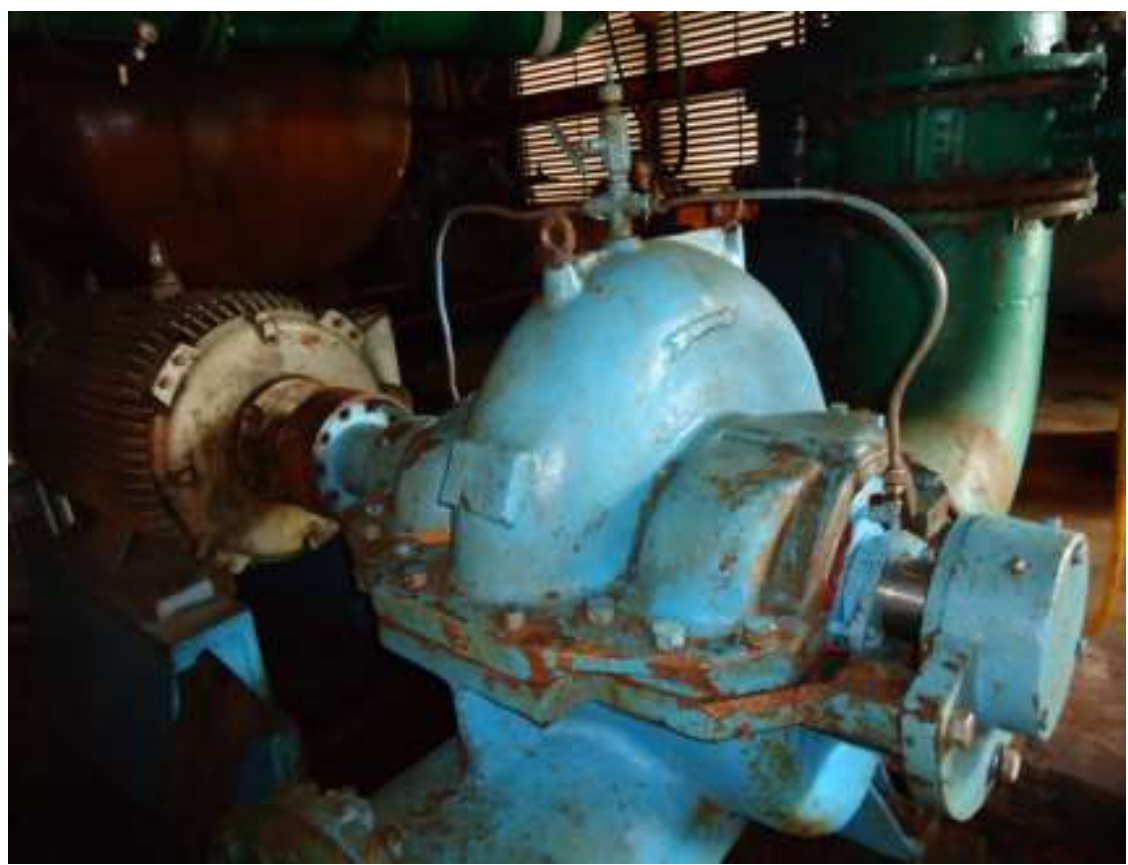

Gambar 7. Open cooling cycle water pump PLTU Labuhan Angin (Sumber : foto peralatan di PLTU Labuhan Angin) 
Tabel 1. Spesifikasi Open Cooling Cycle Water Pump

\begin{tabular}{|c|c|c|}
\hline NO & SPESIFIKASI & KETERANGAN \\
\hline 1 & Type & $400 \mathrm{CS}-20$ \\
\hline 2 & Flow Capacity & $1450 \mathrm{~m} 3 / \mathrm{H}$ \\
\hline 3 & Rotary Speed & $1450 \mathrm{r} / \mathrm{mnt}$ \\
\hline 4 & Head & $20 \mathrm{~m}$ \\
\hline 5 & Motor Power & $132 \mathrm{~kW}$ \\
\hline 6 & Motor Voltage & $380 \mathrm{~V}$ \\
\hline 7 & Motor Ampere & $232 \mathrm{~A}$ \\
\hline 8 & Motor Speed & $1485 \mathrm{r} / \mathrm{mnt}$ \\
\hline 9 & Bearing Pompa & SKF 6313 \\
\hline
\end{tabular}

\subsubsection{Bearing Pompa}

Di sebuah pompa pasti menggunakan bearing atau bantalan yang berfungsi untuk menumpu dan menahan beban dari poros agar dapat berputar, baik berupa beban radial maupun beban axial. Bearing juga memungkinkan poros untuk dapat berputar dengan lancar dan tetap pada tempatnya, sehingga kerugian gesek menjadi kecil. Pada OCCWP yang ada di PLTU Labuhan Angin menggunakan bearing SKF 6313 pada sisi DE dan NDE dengan jenis ball bearing.
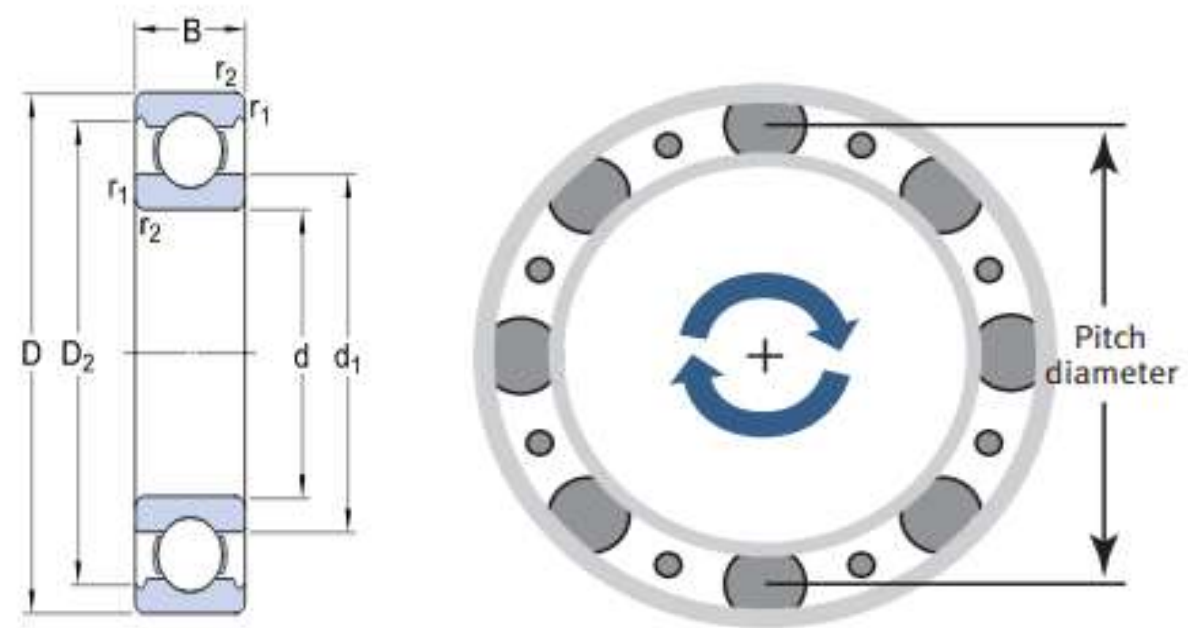

Gambar 8. Bearing SKF 6313

(Sumber : http://www.skf.com/group/products/ 6313-2Z)

Tabel 2. Spesifikasi Bearing SKF 6313 (berdasarkan data pabrikan)

\begin{tabular}{|c|c|c|}
\hline NO & SPESIFIKASI & KETERANGAN \\
\hline 1 & Outer diameter & $140 \mathrm{~mm}$ \\
\hline 2 & Inner diameter & $65 \mathrm{~mm}$ \\
\hline 3 & Pitch diameter $(\mathrm{Pd})$ & $102.5 \mathrm{~mm}$ \\
\hline 4 & Ball diameter $(\mathrm{Bd})$ & $23.8 \mathrm{~mm}$ \\
\hline 5 & Number of ball $(\mathrm{Nb})$ & $8 \mathrm{pcs}$ \\
\hline 6 & Contact angle $(\theta)$ & 0 degree \\
\hline 7 & Speed & $1450 \mathrm{rpm}$ \\
\hline 8 & Frekuensi $(\mathrm{F})$ & $24.2 \mathrm{~Hz}$ \\
\hline
\end{tabular}




\subsubsection{Alat Uji}

Untuk alat uji yang digunakan untuk melakukan penelitian adalah SKF Microlog Analyzer AX-Series CMXA 80. Alat ini merupakan peralatan yang digunakan oleh tim predictive maintenance PLTU Labuhan Angin untuk memonitoring kondisi vibrasi peralatan yang beroperasi.

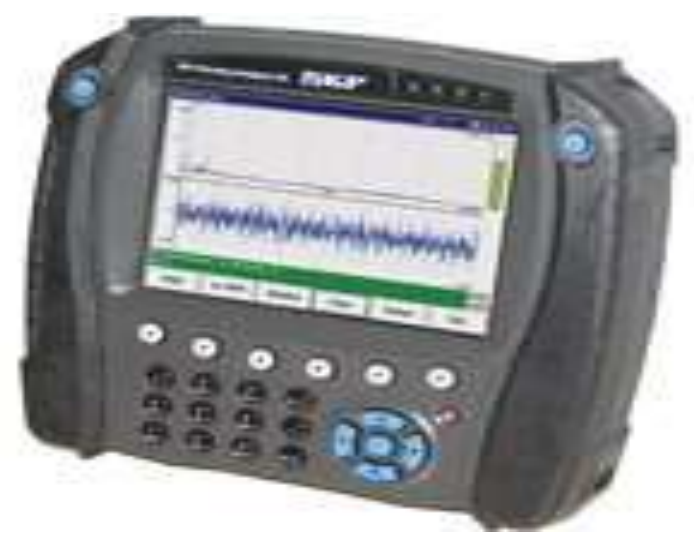

Gambar 9. Vibration Analyzer

(Sumber : http://www.skf.com/group/products)

\subsection{Diagram Alir Penelitian}

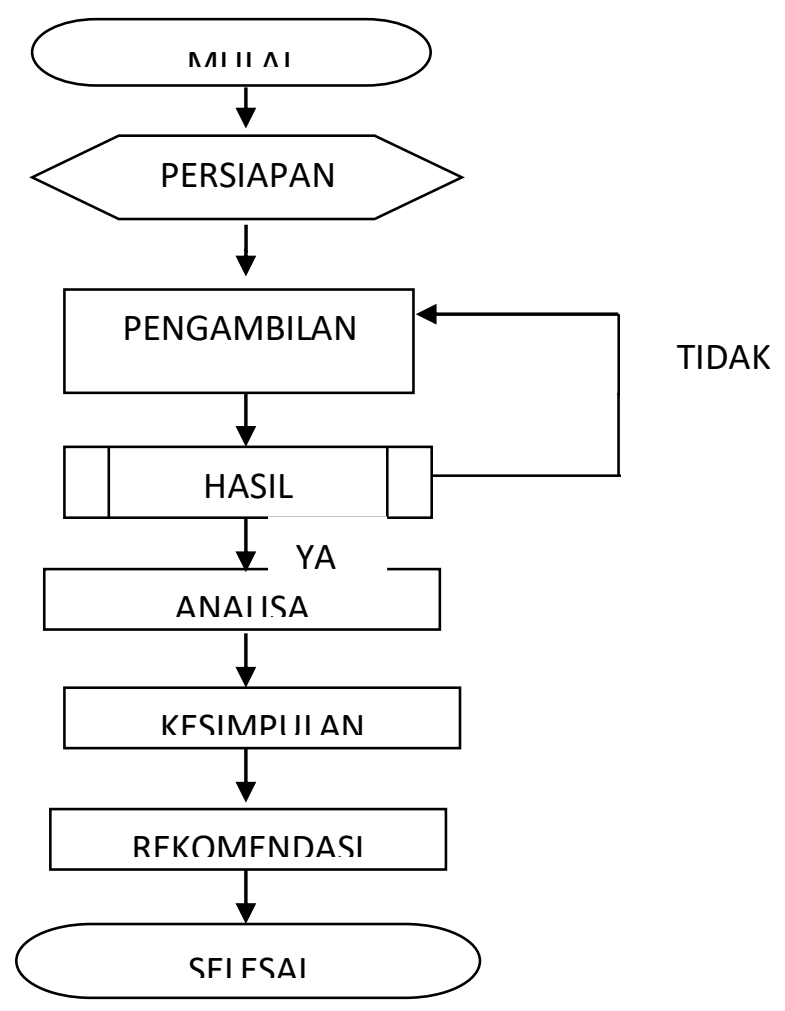

Gambar 10. Diagram Alir Penelitian 


\section{HASIL DAN PEMBAHASAN}

\subsection{Analisa Vibrasi}

Berdasarkan data pengujian vibrasi pada OCCWP di PLTU Labuhan Angin pada tanggal 27 Januari 2015, data pengukuran vibrasi menunjukkan adanya nilai High Frequency Detection (HFD) berada di atas ambang batas pada bagian horizontal bearing pompa sisi DE (pada titik $3 \mathrm{H}$ vel) yang mencapai $13.06 \mathrm{~mm} / \mathrm{s}$.

Tabel 3. Hasil Pengukuran Vibrasi

\begin{tabular}{|c|c|c|c|}
\hline TITIK & Hasil Pengukuran & \multirow{2}{*}{ Satuan } & \multirow{2}{*}{ KET } \\
\cline { 2 - 2 } PENGUKURAN & 27-Jan-15 & & \\
\hline 3H vel & 13.06 & $\mathrm{~mm} / \mathrm{s}$ & Danger \\
\hline 3V vel & 9.708 & $\mathrm{~mm} / \mathrm{s}$ & Warning \\
\hline 3A vel & 5.807 & $\mathrm{~mm} / \mathrm{s}$ & \\
\hline 4H vel & 7.696 & $\mathrm{~mm} / \mathrm{s}$ & Warning \\
\hline 4V vel & 8.116 & $\mathrm{~mm} / \mathrm{s}$ & Warning \\
\hline 4A vel & 5.227 & $\mathrm{~mm} / \mathrm{s}$ & \\
\hline
\end{tabular}

Sumber : hasil pengukuran)

\section{Grafik Pengukuran Vibrasi OCCWP 2A}

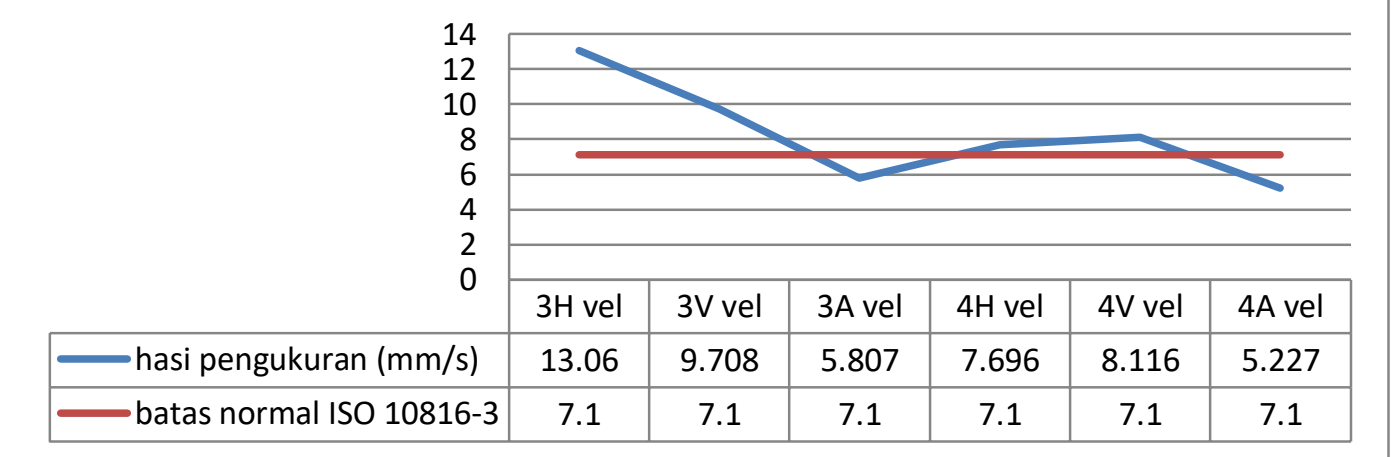

Gambar 11. Grafik hasil pengukuran vibrasi

(Sumber : hasil pengukuran vibrasi)

Nilai standar vibrasi pompa OCCWP 2A berdasarkan ISO 10816-3 adalah 7,1 $\mathrm{mm} / \mathrm{s}$ sedangkan nilai vibrasi yang terdapat pada pompa OCCWP saat dilakukan pengukuran adalah 13,06 mm/s dan nilai tersebut masuk ke dalam kategori D (danger). Peralatan dengan nilai vibrasi yang masuk ke kategori Danger harus segera dilakukan perbaikan untuk menghindari kerusakan yang lebih ekstrim pada peralatan.

Selain nilai vibrasi yang kita dapat dari penggunaan alat vibration analyzer adalah spektrum vibrasi. Gambar 12 adalah hasil spektrum dari pengukuran terhadap OCCWP $2 \mathrm{~A}$. 


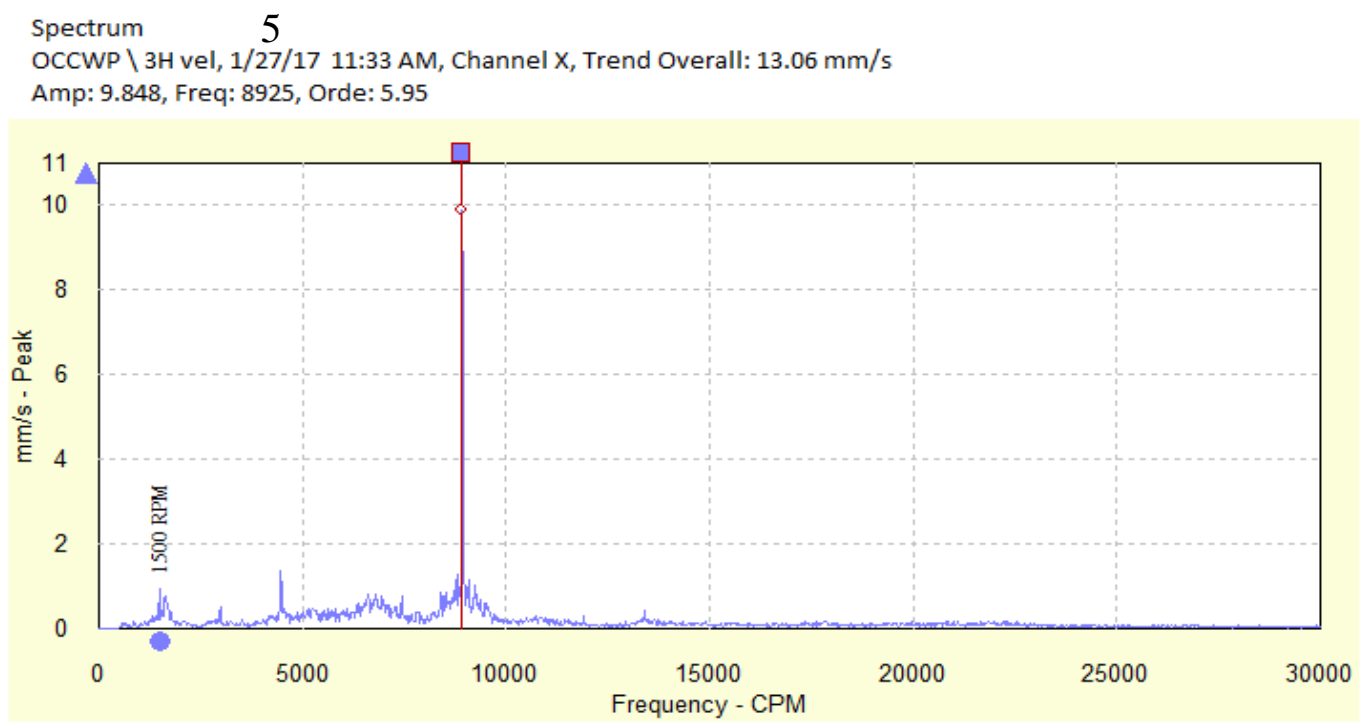

Gambar 12. Grafik Spektrum vibrasi OCCWP 2A

(Sumber : hasil pengukuran)

Dari gambar diatas kita mendapatkan data sebagai berikut :

1) Nilai vibrasi $: 13.06 \mathrm{~mm} / \mathrm{s}$

2) Amplitudo : 9.848

3) Frequensi $: 8925 \mathrm{~Hz}$

4) Orde : :5,95

Kerusakan bearing dimulai ketika spektrum muncul pada frekuensi tinggi ( $20 \mathrm{kHz}$ $60 \mathrm{kHz}$ ) sampai akhirnya menuju ke frekuensi rendah. Di mana apabila spektrum tersebut sudah memasuki frekuensi rendah dan random, maka telah sampai pada tingkat kerusakan yang parah.

Analisa spectrum pada sisi pump inboard horizontal menunjukkan peak spektrum vibrasi muncul pada frekuensi 5.95x orde dengan noise floor disekitaran spektrum dominan. Dari analisa pola dan karakteristik spektrum menunjukkan adanya indikasi bearing defect pada pompa.

Untuk mengidentifikasi jenis karakteristik frekuensi cacat bantalan (bearing) dapat dihitung dengan pendekatan menggunakan persamaan sebagai berikut :

(1) BPFI (ball pass frequency inner race)

$$
\begin{aligned}
\text { BPFI } & =\left(\frac{N b}{2}\right) \times \mathrm{F} \times\left(1+\frac{B d}{P d} \times \operatorname{Cos} \theta\right) \\
& =\left(\frac{8}{2}\right) \times 24.2 \times\left(1+\frac{23.8}{102.5} \times \operatorname{Cos} 0\right) \\
& =119.28 \text { atau }(4.92 \times \text { orde })
\end{aligned}
$$

(2) BPFO (ball pass frequency outer race)

$$
\begin{aligned}
\mathrm{BPFO} & =\left(\frac{N b}{2}\right) \times \mathrm{F} \times\left(1-\frac{B d}{P d} \times \operatorname{Cos} \theta\right) \\
& =\left(\frac{8}{2}\right) \times 24.2 \times\left(1-\frac{23.8}{102.5} \times \operatorname{Cos} 0\right) \\
& =74.53 \text { atau }(3.08 \times \text { orde })
\end{aligned}
$$

(3) FTF (Fundamental train frequency) 


$$
\begin{aligned}
\text { FTF } & =\left(\frac{F}{2}\right) \times\left(1-\frac{B d}{P d} \times \operatorname{Cos} \theta\right) \\
& =\left(\frac{24.2}{2}\right) \times\left(1-\frac{23.8}{102.5} \times \operatorname{Cos} 0\right) \\
& =9.29 \mathrm{~Hz} \text { atau }(0.38 \times \text { orde })
\end{aligned}
$$

(4) BSF (ball spin frequency)

Keterangan:

$$
\begin{aligned}
\mathrm{BSF} & =\left(\frac{P d}{2 B d}\right) \times \mathrm{F} \times\left(1-\left(\frac{B d}{P d} \times \operatorname{Cos} \theta\right)^{2}\right) \\
& =\left(\frac{102.5}{2 \times 23.8}\right) \times 24.2 \times\left(1-\left(\frac{23.8}{102.5} \times \operatorname{Cos} 0\right)^{2}\right) \\
& =48.98 \mathrm{~Hz} \text { atau }(2.02 \times \text { orde })
\end{aligned}
$$

(Berdasarkan tabel 2. Spesifikasi bearing SKF 6313)

$\mathrm{Pd}:$ Pitch diameter

Bd:Ball diameter

$\mathrm{Nb}:$ Number of ball

$\theta$ :Contact angle

$\mathrm{F}$ :Frekuensi

Tabel 4. Corresponding Frequency (order)

\begin{tabular}{|c|c|c|c|c|c|c|c|c|c|c|}
\hline Speed & \multicolumn{10}{|c|}{ Corresponding Frequency (order) } \\
\hline 24.2 Hz & $\mathrm{nl}$ & $\mathrm{n} 2$ & $\mathrm{n} 3$ & $\mathrm{n} 4$ & $\mathrm{n} 5$ & $\mathrm{n} 6$ & $\mathrm{n} 7$ & $\mathrm{n} 8$ & $\mathrm{n} 9$ & $\mathrm{n} 10$ \\
\hline BPFI & 4.92 & 9.84 & 14.76 & 19.68 & 24.6 & 29.52 & 34.44 & 39.36 & 44.28 & 49.2 \\
\hline BPF0 & 3.08 & 6.16 & 9.24 & 12.32 & 15.4 & 18.48 & 21.56 & 24.64 & 27.72 & 30.8 \\
\hline FTF & 0.38 & 0.76 & 1.14 & 1.52 & 1.9 & 2.28 & 2.66 & 3.04 & 4.42 & 3.8 \\
\hline BSF & 2.02 & 4.04 & 6.06 & 8.08 & 10.1 & 12.12 & 14.14 & 16.16 & 18.18 & 20.2 \\
\hline
\end{tabular}

\begin{tabular}{|c|c|c|c|c|c|c|c|c|c|c|}
\hline Speed & \multicolumn{10}{|c|}{ Corresponding Frequency (order) } \\
\hline $24.2 \mathrm{~Hz}$ & $\mathrm{n} 11$ & $\mathrm{n} 12$ & $\mathrm{n} 13$ & $\mathrm{n} 14$ & $\mathrm{n} 15$ & $\mathrm{n} 16$ & $\mathrm{n} 17$ & $\mathrm{n} 18$ & $\mathrm{n} 19$ & $\mathrm{n} 20$ \\
\hline BPFI & 54.12 & 59.04 & 63.96 & 68.88 & 73.8 & 78.72 & 83.64 & 88.56 & 93.48 & 98.4 \\
\hline BPFO & 33.88 & 36.96 & 40.04 & 43.12 & 46.2 & 49.28 & 53.36 & 55.44 & 58.52 & 61.6 \\
\hline FTF & 4.18 & 4.56 & 4.94 & 5.32 & 5.7 & 6.08 & 6.46 & 6.84 & 7.22 & 7.6 \\
\hline BSF & 22.22 & 24.24 & 26.26 & 28.28 & 30.3 & 32.32 & 34.34 & 36.36 & 38.38 & 40.4 \\
\hline
\end{tabular}

Sesuai dengan spesifikasi bearing SKF 6313 dan hasil perhitungan frekuensi elemen bearing di dapat data seperti berikut :

- BPFI berada di frekuensi 4.92

- BPFO berada di frekuensi 3.08

- FTF berada di frekuensi 0.38

- BSF berada di frekuensi 2.02 
Meski bearing diproduksi menggunakan teknologi tinggi, namun bearing juga tetap memiliki ketidaksempurnaan dan menghasilkan getaran. Biasanya karakteristik frekuensi elemen bearing akan mengalami sedikit pergeseran berdasarkan putaran peralatan dan beban kerja peralatan.

Hasil perhitungan frekuensi komponen bearing menunjukkan bahwa frekuensi spektrum yang muncul pada 5.95x orde merupakan frekuensi BSF (ball spin frequency). Hasil perhitungan menunjukkan bahwa corespondency frequency BSF pada $\mathrm{n} 3$ adalah 6.06x orde. Nilai ini yang paling mendekati dari frekuensi spectrum dominan yang muncul di 5.95x orde diantara yang lainnya.

\subsection{Penyebab Kerusakan Bearing Pompa}

Setelah kita ketahui kerusakan yang terjadi pada bearing OCCWP 2A menggunakan analisa vibrasi maka selanjutnya perlu dicari penyebab terjadinya kerusakan bearing yang ada pada pompa tersebut.

Untuk mencari akar permasalahan pada kasus ini kita menggunakan metode fish bone diagram. Menurut Dr. Kaoru Ishikawa diagram tulang ikan atau fishbone adalah salah satu metode/tool di dalam meningkatkan kualitas. Sering juga diagram ini disebut dengan diagram sebab-akibat atau cause effect diagram.

Fungsi dasar diagram fishbone adalah untuk mengidentifikasi dan mengorganisasi penyebab-penyebab yang mungkin timbul dari suatu efek spesifikasi dan kemudian memisahkan akar penyebabnya.

Berikut adalah diagram tulang ikan yang menjelaskan beberapa kemungkinan penyebab permasalahan :

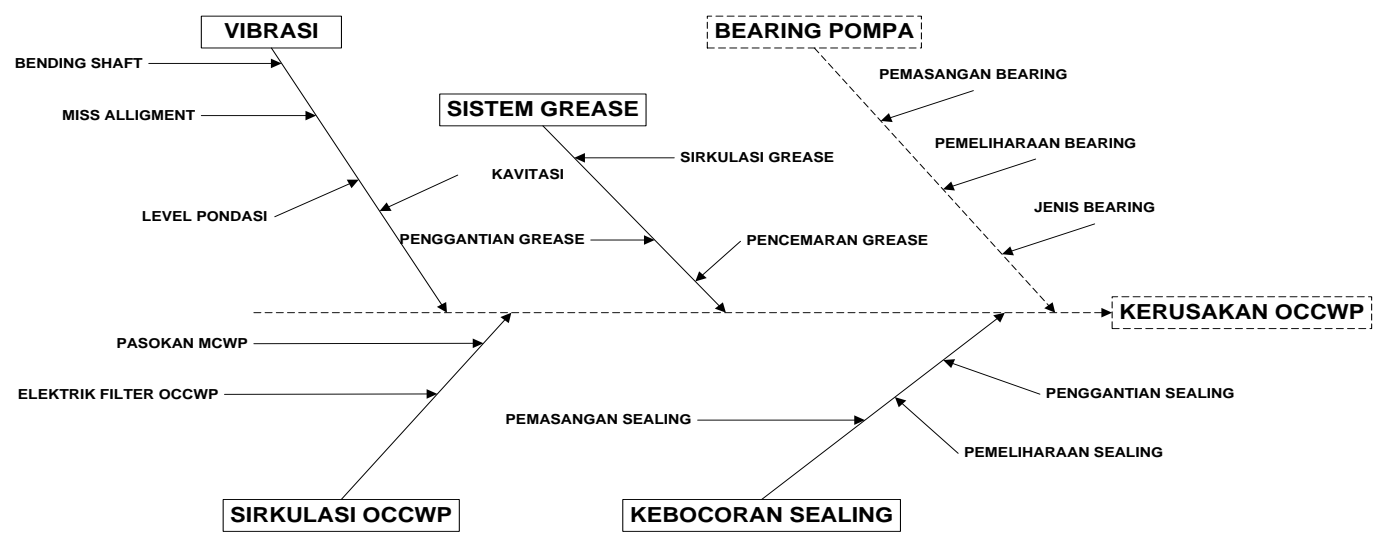

Gambar 13. Diagram tulang ikan

Berikut ini adalah penjelasan penyebab terjadinya kerusakan bearing pada OCCWP:

Kebocoran sealing yang terjadi pada OCCWP 2 sangat berpengaruh besar terhadap kerusakan yang terjadi pada pompa tersebut. Air yang keluar dari kebocoran sealing tersebut adalah air laut. Air laut yang bersifat korosi akan merusak setiap peralatan yang terkena air laut itu sendiri baik baseplate, bearing, rumah pompa motor dan lainnya yang berada disekitar area yang terkena air laut tersebut.

Air laut yang masuk ke dalam bearing housing (rumah bearing) penyebab utama terjadinya kerusakan pada bearing yang selanjutnya menimbulkan vibrasi yang tinggi pada pompa. 


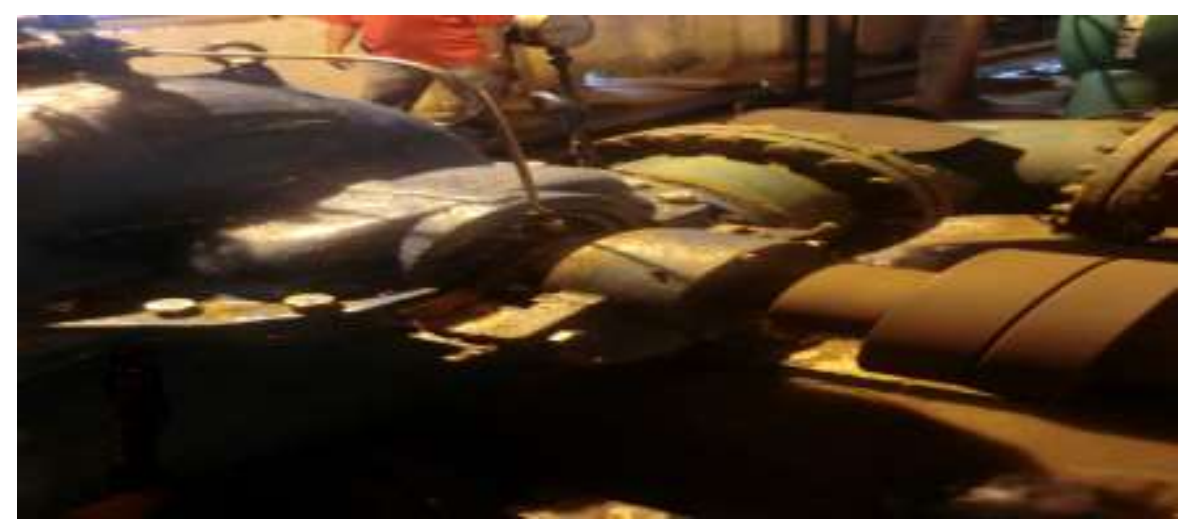

Gambar 14. Kebocoran Sealing Pada OCCWP 2A

\section{KESIMPULAN}

Melihat data yang diperoleh dari pengambilan data dan pembahasan analisa yang telah dilakukan, dapat diambil beberapa kesimpulan sebagai berikut:

1. Kerusakan pada peralatan berputar, dalam hal ini kerusakan bearing pada pompa dapat dideteksi dengan bantuan spektrum vibrasi.

2. Tingginya nilai vibrasi OCCWP $2 \mathrm{~A}$ setelah dianalisa terjadi kerusakan pada bearing bagian BSF (ball spin frequency).

3. Kebocoran yang terjadi pada sealing pada OCCWP 2A merupakan penyebab terjadinya kerusakan pada bearing.

4. Dengan mendeteksi dini kerusakan pada peralatan menggunakan monitoring vibrasi dapat mengurangi cost maintenance akibat rusaknya sebuah peralatan.

\section{DAFTAR PUSTAKA}

1. Girdhar, Paresh. 2004. Practical Machinery Vibration Analysis and Predictive Maintenance. Elsevier. Burlington.

2. Harris, Tedric A and Michael N. Kotzalas. 2007. Essential Concepts of Bearing Technology. CRC Press Taylor \& Francis Group. United States of America.

3. Pruftechnik. 2002. An engineer"s guide - Making the maintenance better (Edition 8). Ismaning: Pruftechnik group

4. Robichaud J Michael, P.Eng. Reference Standards for Vibration Monitoring and Analysis. Bretech Engineering Ltd., 70 Crown Street, Saint John, NB Canada.

5. Schniederjans Mare J, Jamie L. Hamaker, Ashlyn M. Schiederjans. 2004. Information Technology Investment: Decision-making Methodology. World Scientific Publishing Co.Pte.Ltd.Singapore.

6. Taylor, James I.2003. The vibration analysis hand book ( $1^{\text {st }}$ edition).USA : Vibration consultants. 